\title{
Antioxidant and hepatoprotective effects of vitamin $E$ and melatonin against copper-induced toxicity in rats
}

\author{
Mehmet Ali Temiz*, Atilla Temur, Elif Kaval Oguz \\ Yuzuncu Yil University, Faculty of Education, Department of Sciences, 65080, Van, Turkey \\ *For correspondence: Email: matemiz@yyu.edu.tr; Tel: +904445065
}

Sent for review: 24 February 2018

Revised accepted: 20 May 2018

\begin{abstract}
Purpose: To determine the preventive effects of vitamin $E$ and melatonin against acute copper toxicity in rats.

Methods: A total of 28 Wistar albino rats were randomly divided into four equal groups: control, copper sulfate, copper sulfate + vitamin E, and copper sulfate + melatonin. The following were analyzed in all groups: serum enzymes; activity of the antioxidant enzymes superoxide dismutase (SOD), catalase $(C A T)$ and glutathione peroxidase (GPX), protein carbonyl (PC) content. Liver histopathology was also evaluated.

Results: PC levels decreased in rats administered copper sulfate/vitamin $E$ and copper sulfate/melatonin. The activities of SOD, GPX and CAT increased significantly with melatonin and vitamin $E$ administration when compared with administration of copper sulfate alone. Histopathologic features revealed severe degeneration and necrotic changes in rats administered copper sulfate alone. These changes were observed to a lesser extent in the copper sulfate + melatonin group and only minimally in the copper sulfate + vitamin E group.

Conclusion: Vitamin $E$ and melatonin are protective against liver damage caused by copper. Vitamin E, and melatonin may strengthen the antioxidant defense system by inhibiting protein oxidation and enhancing the activity of antioxidant enzymes.
\end{abstract}

Keywords: Copper, Melatonin, Vitamin E, Protein oxidation, Hepatoprotective

\begin{abstract}
This is an Open Access article that uses a funding model which does not charge readers or their institutions for access and distributed under the terms of the Creative Commons Attribution License (http://creativecommons.org/licenses/by/4.0) and the Budapest Open Access Initiative (http://www.budapestopenaccessinitiative.org/read), which permit unrestricted use, distribution, and reproduction in any medium, provided the original work is properly credited.

Tropical Journal of Pharmaceutical Research is indexed by Science Citation Index (SciSearch), Scopus, International Pharmaceutical Abstract, Chemical Abstracts, Embase, Index Copernicus, EBSCO, African Index Medicus, JournalSeek, Journal Citation Reports/Science Edition, Directory of Open Access Journals (DOAJ), African Journal Online, Bioline International, Open-J-Gate and Pharmacy Abstracts
\end{abstract}

\section{INTRODUCTION}

The adult recommended dietary allowance of copper is $900 \mu \mathrm{g} /$ day. In the United States, the median intake of copper from food is approximately $1.0-1.6 \mathrm{mg} /$ day. By comparison, the tolerable upper intake level is $10,000 \mu \mathrm{g} / \mathrm{day}$ (10 mg/day), which represents the limit for prevention of hepatic injury, a potentially serious side effect of excess copper ingestion [1].
Excessive copper intake can occur via the consumption of copper-rich foods such as liver, seafood, nuts, whole grains, and dried fruits. Copper exposure can also occur due to exposure to residues of pesticides [2] commonly used in agriculture as well as via drinking water contaminated by environmental pollution [3] or by corrosion of copper water pipes [4]. Ingested copper can participate in reactions that result in the production of free radicals such as 
superoxide anion $\left(\mathrm{O}_{2}^{--}\right)$. The transformation of $\mathrm{O}_{2}^{\cdot-}$ into hydroxyl radical $(\mathrm{OH} \bullet)$, which has a higher reaction capacity in the Haber-Weiss and Fenton reactions, is the primary factor associated with oxidative stress resulting in tissue damage [5].

Prophylactic use of melatonin and vitamin $E$ for anti-aging and food supplementation has attracted considerable recent interest for possible health improvement and disease prevention in the current era of self-care and complementary medicine $[6,7]$. The use of dietary supplements sources might have beneficial effects, such as enhancing the immune system and the synthesis and bioavailability of nutrients, and reducing the risk of certain cancers and other diseases [7-9]. Melatonin is produced by and released from the pineal gland and reaches peak levels at night. Melatonin has many physiologic functions and plays a role in the regulation of diverse processes, such as circadian rhythm, blood pressure, oncogenesis, chronobiotic function, retinal physiology, immune function, apoptosis, and mitochondrial homeostasis [10]. Tocopherol, the most effective and most powerful form of vitamin $\mathrm{E}$, is an important antioxidant compound with many physiologic functions, including maintenance of plasma membrane integrity, cell signaling and cell cycle regulation, cell adhesion, platelet aggregation, smooth muscle cell proliferation, and immune function [7]. The purpose of this study was to investigate the antioxidant and hepatoprotective effects of vitamin $E$ and melatonin supplementation on liver damage associated with copper exposure in rats.

\section{EXPERIMENTAL}

\section{Animals and experimental protocol}

Experiments were performed using 28 male Wistar albino rats $(200-300 \mathrm{~g} ; 3-4$ months of age) supplied by Experimental Animal Research Center, Yuzuncu Yil University (Van, Turkey). All rats were provided standard laboratory chow for rodents and tap water ad libitum. The amount of copper in the tap water and feed was 0.0044 $\mathrm{mg} / \mathrm{L}$ and $33.51 \mathrm{mg} / \mathrm{kg}$, respectively. The amount of vitamin $E$ ( $\alpha$-tocopherol) in the feed was 67.54 $\mathrm{mg} / \mathrm{kg}$. Rats were housed at $22 \pm 2{ }^{\circ} \mathrm{C}, 50 \%$ humidity, under a 12:12 h reverse light/dark cycle.

Copper was administered at a dose of $10 \mathrm{mg} / \mathrm{kg}$ body weight (bw) as copper sulfate every other day, based on the modified method of Saleha et al [11]. The rats were grouped as follows for experiments: control group, received $1 \mathrm{~mL}$ of physiologic saline (i.p.) every day for 14 days; copper sulfate (CS) group, administered $10 \mathrm{mg}$ $\mathrm{CuSO}_{4} / \mathrm{kg}$ bw (i.p.) every other day for 14 days (on days when copper sulfate was not administered, rats received saline); copper sulfate + vitamin E group (CS + Vit E), administered $10 \mathrm{mg} \mathrm{CuSO} / \mathrm{kg}$ bw (i.p.) every other day plus $40 \mathrm{mg}$ a-tocopherol (as equivalent vitamin E)/kg bw (intramuscularly) [12] every day for 14 days; copper sulfate + melatonin group $(\mathrm{CS}+\mathrm{Mel})$, administered $10 \mathrm{mg} \mathrm{CuSO} / \mathrm{kg}$ bw (i.p.) every other day plus $25 \mathrm{mg}$ melatonin/kg bw (i.p.) [13] every day for 14 days. All rats received humane care according to the international/national guidelines for animal studies $[14,15]$. This investigation was approved by the Ethics Committee of Yuzuncu YIl University (no. 03-27552122-105).

\section{Sample collection}

All 28 rats survived the 14-day experiment. At the conclusion of the experiment, the rats were anesthetized with ketamine $(20 \mathrm{mg} / \mathrm{kg}$, intramuscularly), and blood was collected from the heart and transferred to EDTA tubes. The tubes were centrifuged for $10 \mathrm{~min}$ at $850 \times \mathrm{g}$ to prepare serum for subsequent enzyme analysis. Serum marker enzymes, including aspartate aminotransferase (AST), alanine aminotransferase (ALT), alkaline phosphatase $(\mathrm{ALP})$, lactate dehydrogenase (LDH) and gamma-glutamyltransferase (GGT), were assayed using an auto-analyzer (Roche Modular $\mathrm{P}$, Germany), using specific kits. Levels of serum copper were determined by atomic absorption spectrometry (Thermo Scientific, iCE-3000 series). Liver tissues were dissected and stored at $-80{ }^{\circ} \mathrm{C}$ until analysis. Liver tissues were homogenized for $3 \mathrm{~min}$ in ice-cold phosphatebuffered saline $(\mathrm{pH}$ 7.4) using a titanium probe homogenizer (Bandelin Sonopuls HD 2200) and then centrifuged at $8570 \times g$ for 30 min at $4{ }^{\circ} \mathrm{C}$. The resulting supernatants were used for antioxidant enzyme and protein carbonyl (PC) analysis.

\section{Biochemical evaluation of liver homogenates}

The degree of copper-induced oxidative stress was evaluated by measuring protein oxidation as damaged (oxidized) protein. Protein oxidation (PC) was measured as carbonyl compound using a Cayman's protein carbonyl assay kit (Cayman Chemical, USA, cat. no 10005020), which measures the reaction of carbonyl groups with 2,4-dinitrophenyl to form 2,4dinitrophenylhydrazine [16]. GPx activity in the liver homogenates was determined by the method of Paglia and Valentine [17]. SOD activity was assayed by calculating the percent 
inhibition of formazan dye formation [18]. Catalase activity was estimated by the method of Aebi [19]. The protein content of the homogenates was determined using the modified Lowry method [20]. Antioxidant enzyme activity is expressed as specific activity (EU/mg protein), and the amount of $\mathrm{PC}$ is expressed as $\mathrm{nmol} / \mathrm{mg}$ protein.

\section{Histopathologic analysis}

Liver tissue samples were routinely embedded in paraffin and stained with hematoxylin and eosin. Tissue samples were evaluated under a light microscope (Nikon dxm 1200F).

\section{Statistical analysis}

Data are expressed as mean \pm standard deviation. Significant differences between groups were assessed using one-way analysis of variance followed by Tukey's test. A $p$ value $\leq$ 0.05 was accepted as statistically significant.

\section{RESULTS}

The experiment showed that rats treated with copper sulfate exhibit changes in the levels of various serum enzymes when compared with control rats. Levels of serum enzymes were evaluated as biochemical markers of early acute hepatic damage (Table 1). The results showed that levels of serum enzymes were markedly lower in the CS + Mel and CS + Vit E groups compared with the CS group $(p<0.05)$.

With regard to measurement of liver carbonyl levels as an indicator of protein oxidation, the results showed that $P C$ was significantly higher in the CS group than the control group $(p<0.05)$. However, PC concentrations were significantly lower in the CS + Vit E and CS + Mel groups compared with the CS group (Figure 1A) and were similar to the PC levels found in the control group. The activity of the antioxidant enzymes SOD, GPx, and CAT was lower in the CS group compared with the other groups. By contrast, treating rats with a combination of CS and vitamin $\mathrm{E}$ or melatonin resulted in significant increases in the activities of the aforementioned enzymes in the liver (Figure $1 \mathrm{~B}$ to $1 \mathrm{D}$ ).

The results of histopathologic analyses are summarized in Table 2. Rats in the control group exhibited normal histologic appearance of the liver (Figure 2A). As expected, severe histologic damage was observed in the liver of all rats in the CS group. In all cases, hydropic degeneration and necrosis were observed. Bilirubin pigment deposition (intra-hepatic cholestasis) was detected the in cytoplasm of some hepatocytes. Areas of cloudy-appearing swelling or vacuolar-hydropic degeneration characterized by large foci of hepatocytes with granulated cytoplasm were observed particularly in the periacinar and

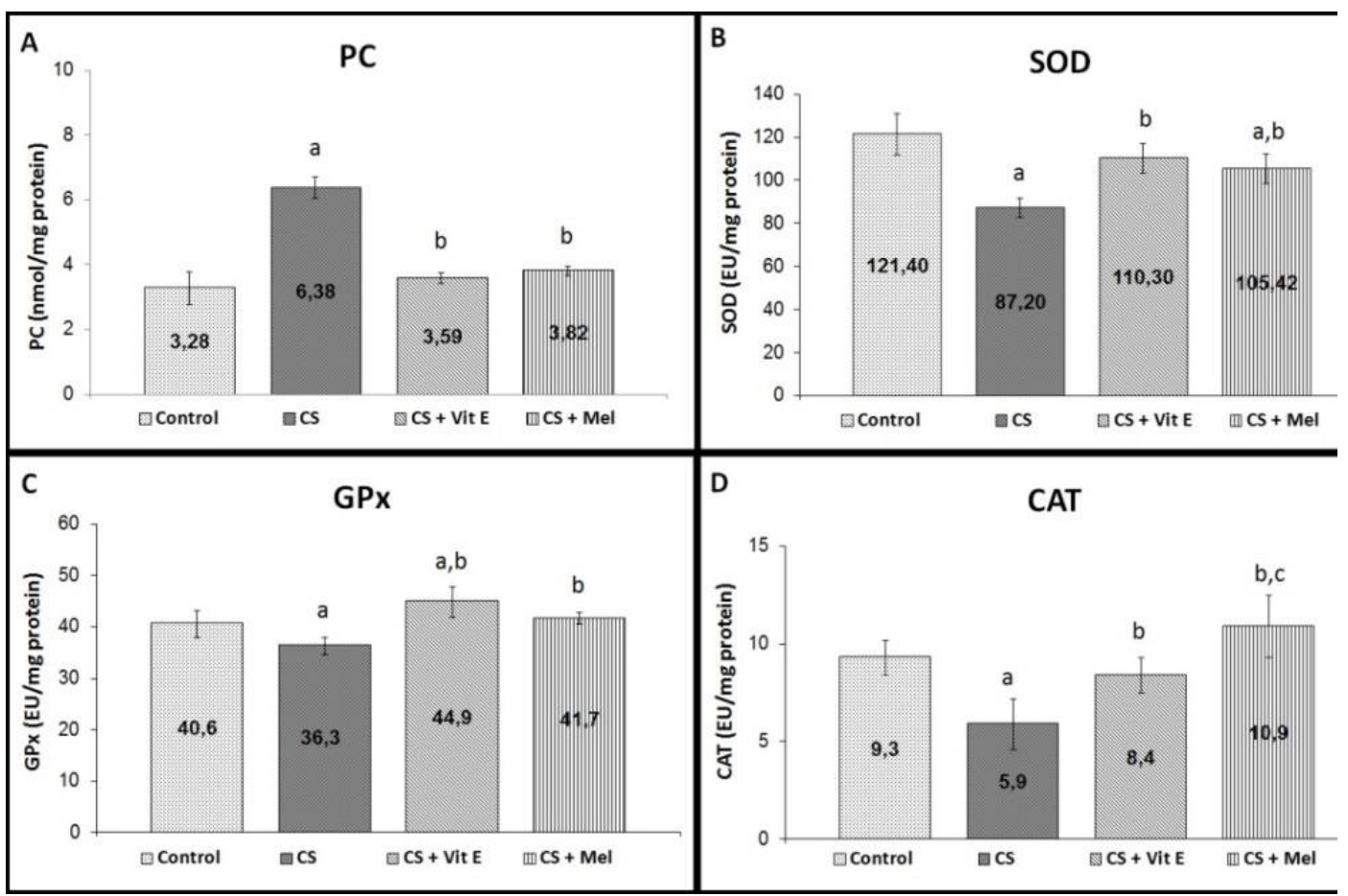

Figure 1: PC content (A) and activities of SOD (B), GPx (C), and CAT (D) in the liver of rats in the Control, CS, $\mathrm{CS}+$ Vit E, and CS + Mel groups. ${ }^{a}$ Significantly different from control $(p<0.05)$; ${ }^{b}$ significantly different from the CS group $(p<0.05)$; ${ }^{\text {c }}$ ignificantly different from the CS + Vit E group $(p<0.05)$ 
intermediate zones of liver lobules. The nucleus was usually located toward the edge of the cell in severely affected hepatocytes and exhibited degeneration or pyknosis. Coagulation necrosis was apparent in hepatocytes around these degenerating cells. The nucleus stained positive for pyknosis in these hepatocytes, and dark staining of the cytoplasm indicated eosinophilia.

Table 1: Activity of serum enzymes

\begin{tabular}{lcccc}
\hline & \multicolumn{4}{c}{ Serum parameter } \\
\hline Serum marker & Control & $\boldsymbol{C S}$ & $\boldsymbol{C S}+$ Vit E & $\boldsymbol{C S}+$ Mel \\
\hline AST U/L & $83,5 \pm 10,1$ & $217,3 \pm 25,4^{\mathrm{a}}$ & $104,2 \pm 14,4^{\mathrm{b}}$ & $97,7 \pm 15,3^{\mathrm{b}}$ \\
ALT U/L & $30,8 \pm 7,4$ & $62,8 \pm 11,8^{\mathrm{a}}$ & $36,5 \pm 5^{\mathrm{b}}$ & $37,3 \pm 7,9^{\mathrm{b}}$ \\
LDH U/L & $759 \pm 124,4$ & $1085,3 \pm 104,4^{\mathrm{a}}$ & $890,3 \pm 37,4^{\mathrm{b}}$ & $674,7 \pm 93,8^{\mathrm{b}, \mathrm{c}}$ \\
GGT U/L & $6,5 \pm 1$ & $11,9 \pm 1,4^{\mathrm{a}}$ & $7,6 \pm 1^{\mathrm{b}}$ & $7,8 \pm 0,7^{\mathrm{b}}$ \\
ALP U/L & $405,3 \pm 34,2$ & $521,2 \pm 46^{\mathrm{a}}$ & $256,7 \pm 31,2^{\mathrm{a}, \mathrm{b}}$ & $354 \pm 21,1^{\mathrm{b}, \mathrm{c}}$ \\
Copper mg/L & $1,048 \pm 0,08$ & $1,491 \pm 0,28^{\mathrm{a}}$ & $1,205 \pm 0,08^{\mathrm{b}}$ & $1,095 \pm 0,05^{\mathrm{b}}$ \\
\hline
\end{tabular}

Values are expressed as mean \pm standard deviation. ${ }^{\text {a: }}$ Significantly different from control $(p<0.05){ }^{0}$

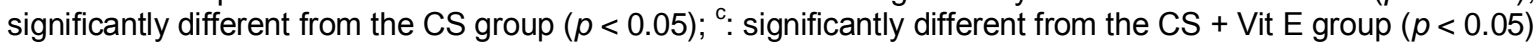

Table 2: Histopathologic changes in rats in the Control, CS, CS + Vit E, and CS + Mel groups

\begin{tabular}{lcccc}
\hline Change/lesions in liver & Control & CS & CS + Vit E & CS + Mel \\
\hline Hydropic degeneration & $-/ 7$ & $7 / 7^{\mathrm{a}}$ & $5 / 7$ & $2 / 7^{\mathrm{D}}$ \\
Mild & $*$ & $*$ & 1 & 1 \\
Moderate & $*$ & 2 & 2 & 1 \\
Severe & $*$ & 5 & 2 & $*$ \\
Necrosis & $-/ 7$ & $7 / 7^{\mathrm{a}}$ & $3 / 7^{\mathrm{b}}$ & $2 / 7^{\mathrm{b}}$ \\
Mild & $*$ & $*$ & 2 & 1 \\
Moderate & $*$ & 3 & 1 & 1 \\
Severe & $*$ & 4 & $*$ & $2 / 7^{\mathrm{D}}$ \\
Cell infiltration & $-/ 7$ & $6 / 7^{\mathrm{a}}$ & $3 / 7$ & 2 \\
Mild & $*$ & $*$ & 1 & $*$ \\
Moderate & $*$ & 1 & 2 & $*$ \\
Severe & $*$ & 5 & $*$ &
\end{tabular}

${ }^{*}$ None; ${ }^{a}$ : Significantly different from control $(p<0.05) ;{ }^{b}$ : significantly different from the CS group $(p<0.05) ;{ }^{c}$ : significantly different from the CS + Vit E group $(p<0.05)$

The arrangement of hepatic cords was disrupted, and sinusoids were narrowed as a result of severe degeneration. The number of perisinusoidal cells was increased, and sinusoidal focal mononuclear cell infiltration was observed. In the portal area, a significant increase in the amount of connective tissue was observed (Figure $2 \mathrm{~B}$ ).

In the CS + Vit E group, large areas of hydropic and parenchymal degeneration were observed in the liver. However, this was not indicative of widespread necrosis and represented only focal coagulation necrosis in hepatocytes. Although this was also observed to a lesser extent in the CS group, the nucleus was often located toward the edge of the affected hepatocytes. In addition, affected hepatocytes were pyknotic or degenerated. Furthermore, intrahepatic cholestasis was frequently observed. The structure of the hepatic cord was disrupted due to degeneration, and sinusoids were narrowed. An increase in the number of perisinusoidal cells and sinusoidal focal mononuclear cell infiltration were observed.

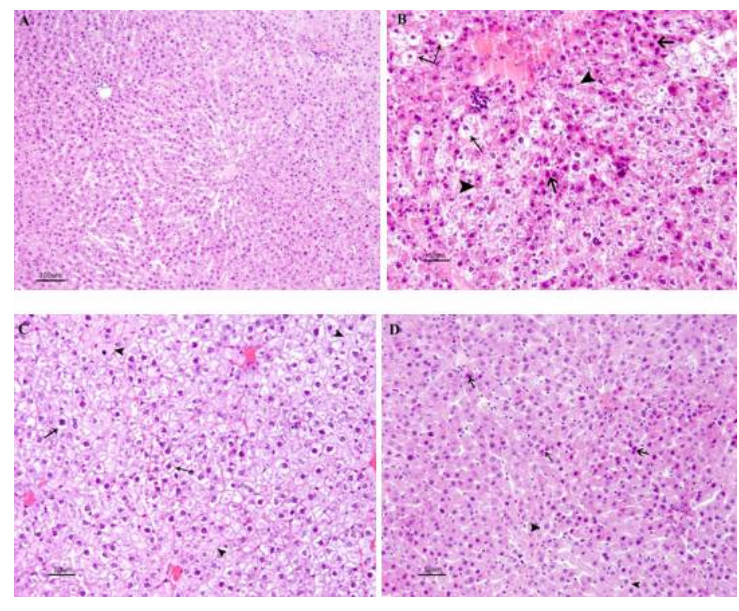

Figure 2: A: Control group, normal histologic appearance of the liver. B: Copper sulfate group, hydropic degeneration of hepatocytes (thin arrows), coagulation necrosis (thick arrows), and intrahepatic cholestasis (arrowheads). C: Copper sulfate + vitamin $\mathrm{E}$ group, hydropic (arrows) and parenchymal (arrowheads) degeneration of hepatocytes. D: Copper sulfate + melatonin group, coagulation necrosis in some hepatocytes (arrows) and parenchymal (arrowheads) degeneration of hepatocytes. Hematoxylin and eosin stain 
However, connective tissue growth was not observed in the portal area (Figure 2C). There were no signs of degeneration or necrosis in the liver of rats in the CS + Mel group. Fewer cell communities exhibited evidence of degeneration, and the cytoplasm of these cells stained pale with a fine granular structure (indicative of parenchymal degeneration). Coagulation necrosis was observed in some hepatocytes. No deterioration in the structure of the hepatic cord was apparent (Figure 2D).

\section{DISCUSSION}

The toxic effects of copper were shown by increased liver enzymes in the serum, high PC content with changes in liver antioxidant enzyme activities, and histopathologic changes in the liver. The activities of transaminase enzymes in serum are known to increase when the integrity of liver cells is disrupted and parenchymal cells degenerate. Copper exposure led to increased ALT and AST levels, confirming the findings of Hwang et al. [21], who treated with a diet supplemented with 150,300 , or 600 ppm copper for 2 months in rats. In a previous study compatible with the present study, Al-Attar [22] reported decreases in serum enzyme levels resulting from the administration of $50 \mathrm{mg}$ vitamin $\mathrm{E} / \mathrm{kg}$ to mice in combination with drinking water containing a mixture of metals.

Intracellular and extracellular multicatalytic proteinases frequently undergo degradation as a result of protein oxidation. The resulting inactivation of functional proteins can lead to a variety of oxidative and pathologic changes [23]. In this study, PC content (an indicator of oxidation) increased significantly in the CS group; however, PC levels decreased significantly in the CS + Vit $\mathrm{E}$ and $\mathrm{CS}+\mathrm{Mel}$ groups. In a previous study, Arnal et al [24] examined the effects of protein oxidation on brain tissue of rats administered 7 or $35 \mathrm{ppm}$ of $\mathrm{CuCO}_{3}$ both orally and i.p. for 30 days. The results of that study [24] and those of the present study clearly demonstrate that copper overloading causes protein oxidation. Many studies have examined lipid peroxidation [24,25], but no studies examining the impact of protein oxidation on rat liver have been published. Several studies, however, have reported that vitamin $E$ and melatonin inhibit copper-induced lipid peroxidation $[5,25]$.

In the present study, the activities of antioxidant enzymes decreased with copper administration. Excessive generation of ROS via the HaberWeiss and Fenton reactions could have led to depletion of antioxidant enzymes [5]. Another possible reason for the decline in enzyme activity is dysfunction resulting from modifications due to protein oxidation [26]. Exposure to excessive levels of copper can cause marked decreases in GSH levels [27]. The observed decrease in GPx activity in the CS group could thus have been associated with the use of GSH as a substrate. However, the activities of SOD, GPx, and CAT increased significantly when vitamin $E$ or melatonin were administered concomitantly with copper. The antioxidant effect of vitamin $E$ is mediated by oxidation of the chromanol ring. Phenolic hydrogen is donated to a fatty acyl free radical to protect the polyunsaturated fatty acids from attack [7]. On the basis of this assumption, it is thought that vitamin $E$ augments the activity of antioxidant enzymes by minimizing oxidative stress. Melatonin is known to increase the gene expression, mRNA half-life stability, and/or activity of a variety of enzymes (e.g., SOD, GPx, GR, glucose-6-phosphate dehydrogenase, and $\mathrm{Y}$-glutamylcysteine synthetase) and thus might diminish oxidative stress $[28,29]$.

The marked increases in the levels of serum enzymes and PC content observed in the present study were indicative of impaired liver function, which was verified by the observation of severe histopathologic damage. The results of the current investigation demonstrate that melatonin reverses copper-induced liver injury. El-Sokkary et al [30] reported that melatonin dramatically inhibits disruption of hepatic cords and increases cytoplasmic vacuolization and inflammatory cell infiltration in lead-induced hepatic toxicity. Furthermore, Eşrefoğlu et al [31] reported that melatonin decreases stressinduced and histopathologic oxidative damage. Kutlubay et al [32] examined the effect of vitamin $E$ on aluminum-induced liver injury and reported that administration of vitamin $E$ significantly reduces dilation of sinusoids and stabilizes the structure of hepatocyte columns. Moreover, Sajitha et al [33] reported that treating lead intoxication with vitamin $E$ reverses tissue damage (i.e., focal necrosis). In this study, although areas of mild degeneration were observed in rats treated with both CS and vitamin $E$, extensive necrosis similar to that observed in CS-treated rats was not detected.

It is likely that the effects of vitamin E observed in the present study are mediation by protection of the microsomal membrane against peroxidative compounds such as oxygen-metal complexes and chain-breaking antioxidant activity [33]. Melatonin, by contrast, is thought to provide protection via (i) a "direct antioxidant effect" involving detoxification of free radicals [34]; (ii) an antioxidant enzyme-mediated effect brought 
about through upregulation of antioxidant enzyme gene expression/activity [35]; or (iii) a "prooxidant enzyme-mediated effect" brought about through inhibition of the activities of prooxidant enzymes, thus reducing the formation of free radicals [34].

\section{CONCLUSION}

Based on the results of this study, it is clear that vitamin $E$ and melatonin prevent protein oxidation and augment the antioxidant defense system. Furthermore, these two powerful antioxidants effectively control the activities of serum enzymes by protecting cell integrity. Although melatonin has a significant effect, vitamin $E$ exhibits partial hepatoprotective and reversible effects that reduce the severity of hepatic degeneration and necrotic changes associated with copper-induced liver damage.

\section{DECLARATIONS}

\section{Acknowledgement}

This research was supported by Yuzuncu Yil University Scientific Research Projects Foundation (grant no. 2013-EF-B025).

\section{Conflict of Interest}

No conflict of interest associated with this work.

\section{Contribution of Authors}

The authors declare that this work was done by the authors named in this article and all liabilities pertaining to claims relating to the content of this article will be borne by them.

\section{REFERENCES}

1. Trumbo $P$, Yates $A A$, Schlicker $S$, Poos M. Dietary reference intakes: vitamin $A$, vitamin $K$, arsenic, boron, chromium, copper, iodine, iron, manganese, molybdenum, nickel, silicon, vanadium, and zinc. J Am Diet Assoc 2001; 101: 294-301.

2. WHO. Copper in drinking-water. Background document for preparation of WHO Guidelines for drinking-water quality. Geneva: World Health Organization. 2003. (WHO/SDE/WSH/03.04/88.

3. Cockell KA, Bertinato J, LÁbbé MR. Regulatory frameworks for copper considering chronic exposures of the population. Am J Clin Nutr 2008; 88: 863S-866S.

4. Brewer GJ. Metals in the causation and treatment of Wilson's disease and Alzheimer's disease, and copper lowering therapy in medicine. Inorg Chim Acta 2012; 393: 135-141.
5. Valko M, Morris $H$, Cronin MT. Metals, toxicity and oxidative stress. Curr Med Chem 2005; 12: 1161-1208.

6. Pham-Huy $L A$, He $H$, Pham-Huy C. Free radicals, antioxidants in disease and health. Int $J$ Biomed Sci 2008; 4(2): 89-96.

7. Combs GF, McClung JP. The Vitamins: Fundamental aspects in nutrition and health. California: Elsevier Academic Press 2017; pp 181-207.

8. Gibson RS. The role of diet- and host-related factors in nutrient bioavailability and thus in nutrient-based dietary requirement estimates. Food Nutr Bull 2007; 28(1): S77S100.

9. Carrillo-Vico A, Lardone PJ, Álvarez-Sánchez N, Rodríguez-Rodríguez A; Guerrero JM. Melatonin: Buffering the Immune System. Int J Mol Sci 2013; 14 : 8638-8683.

10. Hardeland $R$, Cardinali DP, Srinivasan V, Spence DW, Brown GM, Pandi-Perumal SR. Melatonin-A pleiotropic, orchestrating regulator molecule. Prog Neurobiol 2011; 93: 350-384.

11. Saleha Banu B, Ishaq M, Danadevi K, Padmavathi $P$, Ahuja YR. DNA damage in leukocytes of mice treated with copper sulfate. Food Chem Toxicol 2004; 42: 1931 1936.

12. Giray B, Gürbay A, Hincal F. Cypermethrin-induced oxidative stress in rat brain and liver is prevented by Vitamin E or allopurinol. Toxicol Lett 2001; 118: 139146.

13. Zararsiz I, Sarsilmaz M, Tas U, Kus I, Meydan S, Ozan E. Protective effect of melatonin against formaldehydeinduced kidney damage in rats. Toxicol Ind Health 2007; 23: $573-579$.

14. National Research Council. Guide for the care and use of laboratory animals. 8th ed. Washington DC. The National Academies Press. 2011; pp. 1-246.

15. International Council For Laboratory Animal Science (ICLAS). http://iclas.org/guidelines-for-researchers.

16. Levine RL, Garland D, Oliver CN, Amici A, Climent I, Lenz AG, Ahn BW, Shaltiel S, Stadtman ER. Determination of carbonyl content in oxidatively modified proteins. Method Enzymol 1990; 186: 464-478.

17. Paglia DE, Valentine WN. Studies on the quantitative and qualitative characterization of erythrocyte glutathione peroxidase. J Lab Clin Med 1967; 70(1): 158-169.

18. McCord JM, Fridovich I. Superoxide Dismutase. An Enzymic Function for Erythrocuprein (Hemocuprein). J Biol Chem 1969; 244: 6049-6055.

19. Aebi H. Catalase in vitro. Method Enzymol 1984; 105: 121-126.

20. Lowry OH, Rosebrough WI, Farr AL, Randall RJ. Protein measurement with the folin phenol reagent. J Biol Chem 1951; 193: 265-275.

21. Hwang DF, Wang LC, Cheng HM. Effect of taurine on toxicity of copper in rats. Food Chem Toxicol 1998; 36 : 239-244.

22. Al-Attar AM. Vitamin E attenuates liver injury induced by exposure to lead, mercury, cadmium and copper in albino mice. Saudi J Biol Sci 2011; 18: 395-401.

Trop J Pharm Res, June 2018; 17(6): 1030 
23. Stadtman ER. Protein oxidation and aging. Free Rad Res 2006; 40(12): 1250-1258.

24. Arnal N, Dominici L, de Tacconi MTJ, Marra CA. Copperinduced alterations in rat brain depends on route of overload and basal copper levels. Nutrition 2014; 30 : 96-106.

25. Parmar P, Limson J, Nyokong T, Daya S. Melatonin protects against copper-mediated free radical damage. $J$ Pineal Res 2002; 32: 237-242.

26. Nyström T. Role of oxidative carbonylation in protein quality control and senescence. EMBO J 2005; 24: 1311-1317.

27. Speisky H, Gómez M, Burgos-Bravo F, López-Alarcón C, Jullian C, Olea-Azar C, Aliaga ME. Generation of superoxide radicals by copper-glutathione complexes: Redox-consequences associated with their interaction with reduced glutathione. Bioorg Med Chem 2009; 17 : 1803-1810.

28. Reiter RJ, Tan DX, Osuna C, Gitto E. Actions of melatonin in the reduction of oxidative stress. $J$ Biomed Sci 2000; 7: 444-458.

29. Mayo JC, Sainz RM, Antolín I, Herrera F, Martin V, Rodriguez C. Melatonin regulation of antioxidant enzyme gene expression. Cell Mol Life Sci 2002; 59: 1706-1713.
30. El-Sokkary GH, Abdel-Rahman GH, Kamel ES. Melatonin protects against lead-induced hepatic and renal toxicity in male rats. Toxicology 2005; 213: 25-33.

31. Eşrefoğlu $M$, Gül $M$, Ateş $B$, Selimoğlu MA. Ultrastructural clues for the protective effect of melatonin against oxidative damage in cerulein-induced pancreatitis. J Pineal Res 2006; 40: 92-97.

32. Kutlubay R, Oguz EO, Abban G, Turgut S. Amelioration of aluminium-induced liver damage by vitamin $E$. Saudi Med J 2007; 28(2): 197-200.

33. Sajitha GR, Jose R, Andrews A, Ajantha KG, Augustine $P$, Augusti KT. Garlic oil and vitamin e prevent the adverse effects of lead acetate and ethanol separately as well as in combination in the drinking water of rats. Indian J Clin Biochem 2010; 25(3): 280-288.

34. Zhang $H$, Zhang $Y$. Melatonin: a well-documented antioxidant with conditional pro-oxidant actions. Pineal Res 2014; 57: 131-146.

35. Emamgholipour S, Hossein-Nezhad A, Ansari M. Can Melatonin Act as an Antioxidant in Hydrogen PeroxideInduced Oxidative Stress Model in Human Peripheral Blood Mononuclear Cells? Biochem Res Int 2016; 2016 : Article ID 5857940, 1-8. 